\section{Dinucleotide repeat polymorphism at the D22S264 locus}

Claude Marineau, Muriel Aubry, Jean-Pierre Julien and Guy A.Rouleau

Center for Research in Neuroscience, McGill University and the Montreal General Hospital Research Institute, Montreal H3G 1A4, Canada

Source and Description: Cos39 cosmid was obtained from a chromosome 22-enriched library and its partial sequence revealed a zinc finger motif of the Kruppel type (1). A $1 \mathrm{~kb}$ Sau3A I fragment derived from $\operatorname{Cos} 39$ and giving a positive signal when hybridized with a poly(dC-dA)-poly(dG-dT) probe was subcloned into the BamHI site of pBluescript SK + (Stratagene). Partial sequence of this subclone revealed a $(C A)_{19}$ dinucleotide repeat. Sequences flanking this repeat were selected as primers for PCR amplification, and amplify a 200 bp sequence with accession number X62391.

\section{PCR Primers: \\ Cos39-A $=$ 5' $^{\prime}$-ATTAACTCATAAAGGAGCCC-3' $\operatorname{Cos} 39-\mathrm{B}=5^{\prime}-\mathrm{CACCCCACCAGAGGTATTCC-3^{ \prime }}$}

PCR Conditions: PCR is carried out in a volume of $25 \mu \mathrm{l}$ containing 0.5 to $1.0 \mu \mathrm{g}$ of genomic DNA, 13 pmoles of each primer, $1.5 \mathrm{mM} \mathrm{MgCl}_{2}, 50 \mathrm{mM} \mathrm{KCl}, 10 \mathrm{mM}$ Tris $-\mathrm{Cl} \mathrm{pH} 8.3$, $0.2 \mathrm{mM}$ dGTP, $0.2 \mathrm{mM}$ dCTP, $0.2 \mathrm{mM}$ dTTP, $0.025 \mathrm{mM}$ dATP, $2 \mu \mathrm{Ci}^{35} \mathrm{~S}-\mathrm{dATP}$ ( $\approx 1000 \mathrm{Ci} / \mathrm{mmol}$ ), and 0.6 unit of Taq DNA polymerase. Thirty cycles of denaturation at $94^{\circ} \mathrm{C}$ for 1 min, annealing at $63^{\circ} \mathrm{C}$ for $30 \mathrm{sec}$ and elongation at $72^{\circ} \mathrm{C}$ for $1 \mathrm{~min}$ were performed. PCR products (approximately $200 \mathrm{bp}$ ) are then analysed on a $5 \%$ acrylamide denaturing gel.

Frequency: Estimated from 30 chromosomes of Caucasians of Northern European descent. The observed heterozygosity is $\mathbf{0 . 8 0}$.

$\begin{array}{lll}\text { Allele } & \text { Size (bp) } & \text { Frequency } \\ \text { A7 } & 210 & 0.17 \\ \text { A6 } & 208 & 0.20 \\ \text { A5 } & 206 & 0.10 \\ \text { A4 } & 204 & 0.07 \\ \text { A3 } & 202 & 0.07 \\ \text { A2 } & 200 & 0.07 \\ \text { A1 } & 190 & 0.33\end{array}$

Chromosomal Localization: Cos39 was assigned to 22q11.2 using a panel of somatic cell hybrids.

Mendelian Inheritance: Demonstrated in 20 families.

Acknowledgements: This work was supported by a Fellowship (M.A.) and a grant (J.-P.J. and G.A.R.) of the Network of Centers of Excellences on Neural Regeneration and Functional Recovery of Canada.

Reference: 1) Aubry et al., submitted.

\section{Dinucleotide repeat polymorphism at the human CRYB2 gene locus (22q11.2)}

Claude Marineau and Guy A.Rouleau

Center for Resaerch in Neuroscience, McGill University

and the Montreal General Hospital Research Institute,

Montreal H3G 1A4, Canada

Source and Description: BCRY11, a $1 \mathrm{~kb}$ Hind3 fragment isolated from the cosmid MC194 was sequenced (1). A (CA) 15 dinucleotide repeat was detected and sequences flanking this repeat were selected as primers for PCR amplification and amplify an $\sim 200$ bp sequence with accession no. X62390.

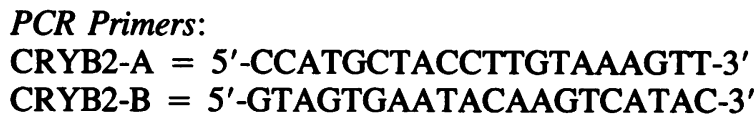

PCR Conditions: PCR is carried out in a volume of $25 \mu \mathrm{l}$ containing 0.5 to $1.0 \mu \mathrm{g}$ of genomic DNA, 13 pmoles of each primer, $1.5 \mathrm{mM} \mathrm{MgCl}$, $50 \mathrm{mM} \mathrm{KCl}, 10 \mathrm{mM}$ Tris-Cl pH 8.3, $0.2 \mathrm{mM}$ dGTP, $0.2 \mathrm{mM}$ dCTP, $0.2 \mathrm{mM}$ dTTP, $0.025 \mathrm{mM}$ dATP, $2 \mu \mathrm{Ci}^{35} \mathrm{~S}-\mathrm{dATP}(\approx 1000 \mathrm{Ci} / \mathrm{mmol}$ ), and 0.6 unit of Taq DNA polymerase. Twenty-five cycles of denaturation at $94^{\circ} \mathrm{C}$ for $1 \mathrm{~min}$, annealing at $55^{\circ} \mathrm{C}$ for $30 \mathrm{sec}$ and elongation at $72^{\circ} \mathrm{C}$ for $1 \mathrm{~min}$ were performed. PCR products (approximately 200 bp) are then analysed on a $5 \%$ acrylamide denaturing gel.

Frequency: Estimated from 30 chromosomes of Caucasians of Northern European descent. The observed heterozygosity is $\mathbf{0 . 6 0}$.

$\begin{array}{lll}\text { Allele } & \text { Size (bp) } & \text { Frequency } \\ \text { B1 } & 212 & 0.13 \\ \text { B2 } & 210 & 0.20 \\ \text { B3 } & 208 & 0.10 \\ \text { B4 } & 206 & 0.07 \\ \text { B5 } & 204 & 0.03 \\ \text { B6 } & 202 & 0.07 \\ \text { B7 } & 200 & 0.40\end{array}$

Chromosomal Localization: BCRY11 was assigned to 22q11.2 using a panel of somatic cell hybrids.

Mendelian Inheritance: Demonstrated in 20 families.

Acknowledgements: GAR is supported by the Medical Research Council of Canada and by the Fonds de Recherche en Santé du Québec. This work was supported by the Medical Research Council of Canada.

References: 1) Fontaine,B., Harvey,M., Haines,J.L., Gorin,M.B., Gusella,J.F. and Rouleau;G.A. (1989) in Karger,S: Humen Gene Mapping 10 Cytogenetics and Cell Genetics 51 (1-4): 999. 